\title{
Some effects of overfeeding for four days in man
}

\author{
Bx J. A. STRONG AND D. SHIRLING \\ Department of Medicine, Western General Hospital \\ AND R. PASSMORE \\ Department of Physiology, University of Edinburgh \\ (Received 3 May 1967-Accepted 13 fuly 1967)
}

\begin{abstract}
r. Food which provided from 2960 to $7880 \mathrm{kcal}$ in excess of requirements was eaten by sixteen subjects, ten hospital patients and six students, in each instance for a period of 4 days.

2. The proportion of the nutrients lost in the faeces was not increased during overfeeding.

3. The metabolic rates were in no instance increased by an amount equivalent to more than $15 \%$ of the excess calories. The increase could be attributed to the specific dynamic action of the extra dietary protein.

4. The gains in weight ranged from 370 to $5460 \mathrm{~g} / 4$ days and the calorie equivalent of the weight gained varied from I.I to $10.0 \mathrm{kcal} / \mathrm{g}$. These variations can be attributed to variations in the amount of water retained.

5. Analysis of their respiratory exchanges suggests that most subjects stored from 400 to I $500 \mathrm{~g}$ of carbohydrate in the tissues, possibly in the form of muscle glycogen.
\end{abstract}

Studies on starvation carried out under good laboratory conditions have been numerous. As a result, it is possible to give a detailed account of the adaptive changes that take place in the human body when the dietary energy is insufficient to meet requirements. By contrast, very few attempts have been made to study the effect of a dietary surfeit on man under experimental conditions. There will be no dispute with the statement that dietary excess ultimately leads to an increase in body fat, but the question remains whether the body has any method of disposing of a temporary excess. Is there any adaptive mechanism that protects the body against a surfeit? If such a mechanism exists, then a failure in its operation might be responsible for the development of obesity.

Previous papers have recorded the effects of overfeeding three thin young men for I4 days (Passmore, Meiklejohn, Dewar \& Thow, I955 $a, b$ ) and two obese women for 9 days (Passmore, Strong, Swindells \& el Din, I963). In this paper we record observations on sixteen subjects, some thin and some fat, of whom each was deliberately overfed for a period of 4 days while living in the metabolic ward of a hospital. A complete energy balance for the period of overfeeding was prepared for each subject. The findings on the five subjects previously reported have been recalculated to cover the first 4 days of overfeeding and combined with results for eleven new subjects.

\section{EXPERIMENTAL}

The subjects. Table I gives their ages, heights and weights. The subjects in this and subsequent tables are arranged in increasing order of adiposity, based on the standard of Odier \& Mach (I949). The first subject, Elizabeth, was a patient who came to 
hospital complaining of thinness. No physical cause for this was found. The next six subjects were healthy students, the first five being selected for their thinness. Edgar was referred to the hospital on account of hypogonadism and found to be a case of Klinefelter syndrome. The last eight subjects all came to hospital on account of their obesity, but were otherwise healthy. They had no obvious endocrine or metabolic abnormality.

\begin{tabular}{|c|c|c|c|c|}
\hline Subject & $\begin{array}{c}\text { Age } \\
\text { (years) }\end{array}$ & $\begin{array}{l}\text { Height } \\
\text { (cm) }\end{array}$ & $\begin{array}{l}\text { Weight } \\
\text { (kg) }\end{array}$ & $\begin{array}{l}\text { Weight as \% of } \\
\text { standard weight }\end{array}$ \\
\hline Elizabeth & 21 & 152 & $3^{8}$ & 74 \\
\hline Tony & 22 & 178 & 57 & $8 I$ \\
\hline Michael & 21 & 180 & 59 & 82 \\
\hline John & 19 & 171 & 54 & 83 \\
\hline David & 22 & 180 & 62 & 85 \\
\hline Sam & 24 & 172 & 57 & 86 \\
\hline Tom & 21 & 170 & 69 & 108 \\
\hline Edgar & 24 & I 78 & 87 & 123 \\
\hline Betty & 35 & 167 & 92 & 146 \\
\hline Pat & 25 & I 68 & 93 & 146 \\
\hline Lena & 24 & I 66 & 93 & 150 \\
\hline Georgette & 38 & I 59 & 94 & 165 \\
\hline May & 17 & I53 & 93 & I 78 \\
\hline Irene & 20 & I 54 & 100 & I 89 \\
\hline Isobel & 30 & I 56 & I I 4 & 209 \\
\hline Ann & 35 & 168 & 146 & 226 \\
\hline
\end{tabular}

Regimen. The subjects were resident in the metabolic ward of the hospital. They were in bed for 8-1o h each night; the rest of the day they were up and dressed and for the most part sitting either reading or watching television. All of them went out each day for a period of formal exercise, which consisted of walking. The exercise varied greatly. For the first ten subjects, it was approximately I h daily, but for the next five, all obese, it was limited to about $30 \mathrm{~min}$. Ann, however, walked for $3 \mathrm{~h}$ on most days. The differences in the amount of exercise taken by the subjects is reflected in the wide variation in daily rates of energy expenditure.

All the subjects were weighed each morning on a beam balance, when clad only in a light surgical gown. The balance was sensitive to changes of I $\mathrm{g}$.

Before the period of overfeeding, all the subjects, except Elizabeth, Georgette and Ann, were in the metabolic ward on a diet calculated to meet their energy requirements, which maintained their weight at a constant level. Elizabeth had previously been on a high-calorie diet, aimed at increasing her body-weight. Both Georgette and Ann, immediately before overfeeding, had been on a low-calorie reducing diet.

Diets. These were composed of ordinary foods, chosen after discussion with each patient. The amount of excess food, which the patients could be persuaded to take, was generally greater in the thin subjects than in the obese. It was perhaps not surprising that the obese subjects, who had in the first instance come to hospital for the treatment of their obesity, should find difficulty in taking excess food. Ann, the obese subject, who took most exercise, was able to eat much more than any of the others.

An aliquot sample of each day's diet was weighed out and homogenized. It was 
dried and the water content determined. The dried sample was analysed for calories (bomb calorimeter), nitrogen content (Kjeldahl), fat (Soxhlet extraction) and ash. The carbohydrate content was determined by difference: two estimates were available, one from the weight of dried solids minus the weight of protein, fat and ash, and the other derived from the bomb calorimeter value, minus the estimated energy content of the protein and fat. The two estimates for the daily carbohydrate intake always agreed within $\mathbf{I}-\mathbf{2} \%$.

Faeces. Stools were collected and weighed daily. A pooled sample was collected over 4 days, discarding the Ist day's faeces when overfeeding, but including the faeces

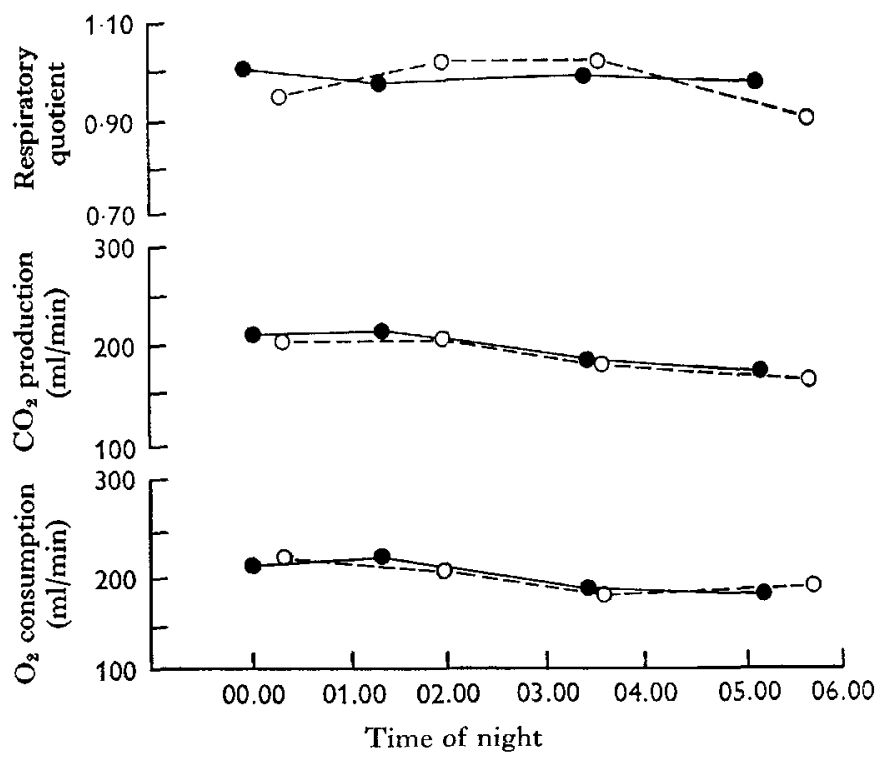

Fig. I. Comparison of measurements of $\mathrm{O}_{2}$ uptake, $\mathrm{CO}_{2}$ production and Re values throughout the night in a subject, measured by the Douglas bag technique $(\mathrm{O}-\mathrm{O})$ and the Noyon's diaferometer (-)

passed on the day after overfeeding ceased. None of the subjects had diarrhoea when overfeeding. Tony, however, had a mild attack during the control period, and though much improved during the overfeeding period, the output of faeces was a little higher than in the other subjects.

The dried samples of faeces were analysed in the same manner as the diet.

Urine. This was collected over a $24 \mathrm{~h}$ period. It was weighed and the volume recorded. The urinary $\mathrm{N}$ was measured by the Kjeldahl method. The calorie value of the urine was calculated by multiplying the $\mathrm{N}$ content by $7 \cdot 9$ (Atwater $\&$ Bryant, I900). All samples of urine were tested for glucose by the 'Clinistix' glucose oxidase test with negative results, except in the case of Isobel, who passed up to $10 \mathrm{~g}$ of glucose in the urine daily.

Energy expenditure. Each subject kept a diary in which their daily activities were recorded minute by minute throughout the $24 \mathrm{~h}$ (Durnin \& Passmore, 1967). Numerous measurements of $\mathrm{O}_{2}$ consumption and $\mathrm{CO}_{2}$ output were made throughout 
the day and night. In the early experiments, measurements were made in the ward using the classical Douglas bag method with gas analyses by the Lloyd-Haldane method. In later experiments, a Noyons diaferometer (Kipp \& Zonen; Delft, Holland) was used, which greatly facilitated the work. In numerous checks, the two methods were found to give identical results, as is illustrated in Fig. I. When walking outside the unit, energy exchanges were determined with the Max Planck respirometer.

Metabolic mixture. This was calculated from estimates of daily $\mathrm{O}_{2}$ consumption, $\mathrm{CO}_{2}$ output and urinary N. Classical conversion factors were used with the arithmetic procedure described by Davidson \& Passmore (I966).

Water balance. A complete daily water balance was drawn up as described by Passmore, Strong \& Ritchie (1959).

\section{RESULTS}

\section{Energy balance}

Table 2 sets out the net dietary calorie intake, the energy expenditure, the excess of calories over expenditure and the weight gained. As already mentioned, the thin subjects for the most part consumed a greater calorie excess than the obese. However, contrary to the findings of the earlier studies, which lasted for a longer period (Passmore et al. 1955a, $b$; Passmore et al. 1963) the lean did not gain less weight. Some of the obese subjects, e.g. May and Irene, gained very little weight, even when allowance is made for their relatively small dietary excess.

Table 2. Net dietary intake, energy expenditure and weight gain of the sixteen subjects during 4 days of overfeeding

$\begin{array}{lcccc}\text { Subject } & \begin{array}{c}\text { Net dietary } \\ \text { energy intake expenditure } \\ \text { (kcal/day) }\end{array} & \begin{array}{c}\text { Energy } \\ \text { (kcal/day) }\end{array} & \begin{array}{c}\text { Excess } \\ \text { energy } \\ \text { (kcal/4 days) }\end{array} & \begin{array}{c}\text { Weight gain } \\ \text { in } 4 \text { days } \\ \text { (g) }\end{array} \\ \text { Elizabeth } & 3720 & 2090 & 6520 & 1210 \\ \text { Tony } & 3900 & 2260 & 6560 & 2410 \\ \text { Michael } & 3970 & 2190 & 7120 & 1360 \\ \text { John } & 4050 & 2220 & 7320 & 2400 \\ \text { David } & 3730 & 2430 & 5200 & 830 \\ \text { Sam } & 3920 & 2210 & 6840 & 1300 \\ \text { Tom } & 3730 & 1920 & 7240 & 2190 \\ \text { Edgar } & 4600 & 2630 & 7880 & 2660 \\ \text { Betty } & 4050 & 3060 & 3960 & 1260 \\ \text { Pat } & 4310 & 3100 & 4800 & 1990 \\ \text { Lena } & 3120 & 2160 & 3840 & 830 \\ \text { Georgette } & 3030 & 2070 & 3840 & 860 \\ \text { May } & 3090 & 2080 & 4040 & 400 \\ \text { Irene } & 3230 & 2300 & 3720 & 370 \\ \text { Isobel } & 3370 & 2630 & 2960 & 1500 \\ \text { Ann } & 5240 & 3770 & 5880 & 5460\end{array}$

Faecal losses

Table 3 gives the faecal losses for twelve subjects during the control period and overfeeding. Results for Elizabeth, Georgette and Ann are not available, as they were not studied during a control period. Results for Tony were omitted in drawing up the mean values, because, as already mentioned, he had slight diarrhoea throughout. 
It will be seen that the faecal losses were relatively no greater during the overfeeding period than during the control period. Furthermore, there was no difference between the losses in the thin and in the obese subjects. The average faecal loss of calories during overfeeding was 4.9 and $4.5 \%$ of the dietary intake for the thin and obese subjects respectively, a difference which was not significant. The only evidence of a limited power of absorption was found in the case of Ann. In the overfeeding period she had a huge daily dietary intake of $2 \mathrm{r} 2 \mathrm{~g}$ fat; of this $26 \mathrm{~g}$ appeared in the faeces.

These findings thus provide no evidence that the body can adapt to an increased dietary intake by rejecting a part of the excess in the faeces. In these subjects the alimentary canal appeared unable to control the supply to the tissues of any of the nutrients studied.

Table 3. Dietary intakes and faecal losses

(Mean daily values for twelve subjects; observations over 4-day periods)

$\overbrace{\begin{array}{c}\text { Intake } \\ (\mathrm{g})\end{array}}^{\text {Balanced diet }} \underset{\begin{array}{c}\text { Faecal loss } \\ (\% \text { of intake })\end{array}}{\text { B. }}$

\begin{tabular}{|c|c|}
\hline \multicolumn{2}{|c|}{ Overfeeding } \\
\hline $\begin{array}{l}\text { Intake } \\
(\mathrm{g})\end{array}$ & $\begin{array}{l}\text { Faecal loss } \\
\text { (\% of intake) }\end{array}$ \\
\hline
\end{tabular}

Solids
Protein
Fat
Carbohydrate
Ash
Energy

491
98
94
282
17
2580
$(\mathrm{kcal})$

$5 \cdot 5$
$8 \cdot 7$
$4 \cdot 0$
$3 \cdot 6$
25
$5 \cdot 2$

$\begin{array}{cc}818 & 4.5 \\ 135 & 9.4 \\ 115 & 4.5 \\ 545 & 2 \cdot 3 \\ 23 & 25 \\ 4070 & 4.7 \\ \text { (kcal) } & \end{array}$

Table 4. Energy expenditure throughout the night (23.00-07.00 h) and basal metabolic rate of eight subjects on a balanced diet and when overfed

\begin{tabular}{lccccc} 
& \multicolumn{2}{c}{ Energy expenditure $(\mathrm{kcal} / 8 \mathrm{~h})$} & \multicolumn{2}{c}{ Basal metabolism (ml $\left.\mathrm{O}_{2} / \mathrm{min}\right)$} \\
\cline { 2 - 3 } Subject & Balanced & Overfed & Balanced & Overfed \\
Tony & 490 & 523 & & 204 & 216 \\
Michael & 523 & 562 & 227 & 230 \\
John & 528 & 542 & 205 & 212 \\
David & 538 & 552 & 273 & 265 \\
Sam & 466 & 538 & 229 & 234 \\
Tom & 484 & 547 & 207 & 211 \\
Betty & 624 & 710 & 271 & 270 \\
Pat & 658 & 706 & 271 & 278 \\
Mean & 539 & 585 & 236 & 240
\end{tabular}

\section{Metabolic rates}

It is not possible to compare the total energy expenditure throughout the $24 \mathrm{~h}$, when on the control diet and when overfeeding, because the amount of active exercise varied slightly from day to day. However, in both periods all the subjects were in bed for $8 \mathrm{~h}$ from 23.00 to $07.00 \mathrm{~h}$. During the night, several measurements of energy expenditure were made, usually at 2 hourly intervals. Table 4 shows a comparison of the estimates of energy expenditure over this period. On average, overfeeding raised the energy output by $46 \mathrm{kcal} / 8 \mathrm{~h}$ or $8.5 \%$. This extra energy output was not incurred 
at a uniform rate. During overfeeding the metabolic rate was some $20 \%$ higher in the earlier part of the night, fell progressively and had disappeared at $07.00 \mathrm{~h}$ in the morning, when basal metabolic rates were measured (Table 4). Fig. 2 illustrates this fall in the night, both during the control period and when overfeeding, for one subject (John). Similar records were obtained for the other subjects. The higher rates at the earlier part of the night can be attributed to the specific dynamic action of the last meal. When overfeeding, the protein intake was higher and the specific dynamic

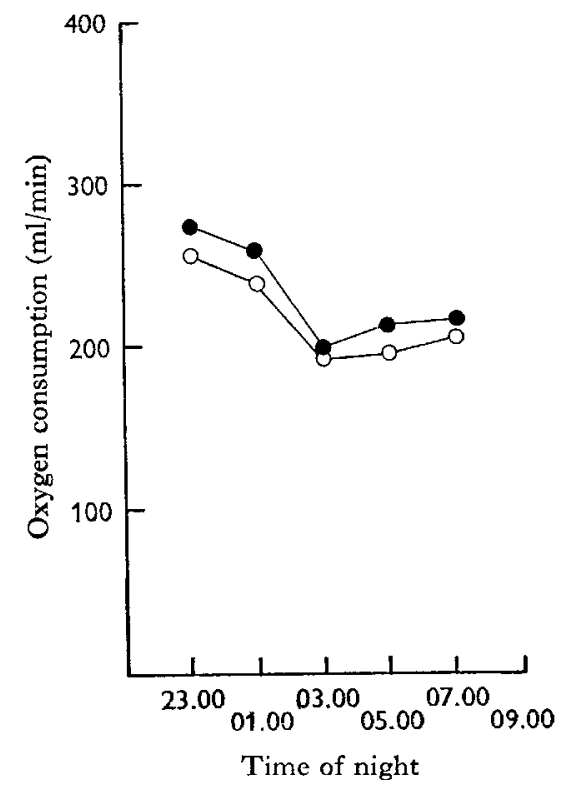

Fig. 2. Rates of $\mathrm{O}_{2}$ uptake of subject John throughout the night when on a balanced diet $(\mathrm{O}-\mathrm{O})$ and when overfed (-)). Each point represents the mean of observations made on 4 successive nights.

effect was also presumably higher. There was thus no evidence in either the lean or the fat that overfeeding for 4 days acted as a general stimulus to metabolism, which might have been responsible for 'burning off' a part of the dietary calorie excess (luxus konsumption-Grafe \& Graham, I9 I I). It must be emphasized that the average excess energy intake of the eight subjects in Table 4 amounted to $1530 \mathrm{kcal} / 24 \mathrm{~h}$. The increase in the metabolic rates throughout the day and night amounted to some $300 \mathrm{kcal} / 24 \mathrm{~h}$ or only about $20 \%$ of the dietary excess.

\section{Changes in body composition}

Gain in body protein, fat and carbohydrate. Tables 5-7 show these gains calculated by subtracting from the net dietary intakes the amounts of each nutrient oxidized by the tissues. These amounts (the metabolic mixture) were calculated from the daily estimates of total $\mathrm{O}_{2}$ consumption, $\mathrm{CO}_{2}$ output and urinary $\mathrm{N}$.

In the 4 days of overfeeding, twelve of the sixteen subjects retained $\mathrm{N}$ corresponding to gains of from 50 to $240 \mathrm{~g}$ protein. The amounts of protein laid down do not appear 
to be closely related to the dietary protein intake (Table 5). The amounts laid down are probably a reflection of the state of the 'labile protein reserve' (Munro 1964) at the start of the period of overfeeding.

Table 5. Changes in protein stores of sixteen subjects, calculated from the nitrogen balance

$\begin{array}{lcc}\text { Subject } & \begin{array}{c}\text { Daily protein intake } \\ \text { (g) }\end{array} & \begin{array}{c}\text { Protein equivalent } \\ \text { of } \mathrm{N} \text { retained } \\ \text { (g/4 days) }\end{array} \\ \text { Elizabeth } & \text { I53 } & 38 \\ \text { Tony } & \text { I50 } & \text { I43 } \\ \text { Michael } & \text { I30 } & 73 \\ \text { John } & \text { I34 } & 55 \\ \text { David } & \text { I39 } & 60 \\ \text { Sam } & \text { I30 } & 30 \\ \text { Tom } & \text { I } 7 & 93 \\ \text { Edgar } & \text { I } 86 & 240 \\ \text { Betty } & \text { I45 } & 53 \\ \text { Pat } & \text { I46 } & 95 \\ \text { Lena } & \text { I47 } & 73 \\ \text { Georgette } & \text { IOI } & 83 \\ \text { May } & \text { I47 } & \text { I85 } \\ \text { Irene } & \text { IOI } & 30 \\ \text { Isobel } & \text { I I } & -22 \\ \text { Ann } & \text { I52 } & \text { I } 80\end{array}$

Table 6. Changes in stores of fat in sixteen subjects, calculated from the dietary intake and metabolic mixture*

\begin{tabular}{|c|c|c|c|}
\hline Subject & $\begin{array}{c}\text { Net dietary } \\
\text { intake } \\
\text { (g/day) }\end{array}$ & $\begin{array}{l}\text { Net tissue } \\
\text { oxidation } \\
\text { (g/day) }\end{array}$ & $\begin{array}{c}\text { Tissue store } \\
\text { (g/4 days) }\end{array}$ \\
\hline Elizabeth & I $4 \mathrm{I}$ & -9 & +600 \\
\hline Tony & I35 & 9 & +504 \\
\hline Michacl & 162 & $8 I$ & +324 \\
\hline John & 92 & -35 & +508 \\
\hline David & I 78 & $\times 65$ & +52 \\
\hline Sam & I 62 & 63 & +396 \\
\hline Tom & 133 & 30 & +412 \\
\hline Edgar & 128 & 22 & +424 \\
\hline Betty & $8 \mathrm{I}$ & 102 & -84 \\
\hline Pat & 88 & $5^{2}$ & +144 \\
\hline Lena & 103 & -9 & +448 \\
\hline Georgette & 125 & 72 & +213 \\
\hline May & IOI & $6 I$ & +160 \\
\hline Irene & IIO & $-2 I$ & +356 \\
\hline Isobel & 94 & 2 & +368 \\
\hline Ann & I 86 & 132 & +216 \\
\hline
\end{tabular}

The fact that all but one of the subjects increased their stores of body fat (Table 6) is hardly surprising. What does merit comment is the apparent finding (Table 7 ) that large amounts of carbohydrate appear to have been laid down. Of the total $88000 \mathrm{kcal}$ taken in by the sixteen subjects in excess of the energy utilized in the tissues, it can be calculated that $9 \%$ was laid down in the form of protein, $35 \%$ as fat and $36 \%$ as 
carbohydrate. This calculation depends entirely on the reliability of the measurements of the respiratory quotients $(\mathrm{RQ})$ as an index of the relative amount of fat and carbohydrate in the metabolic mixture. As is well known, the RQ is unreliable if the subject is consistently overbreathing or underbreathing and so blowing off or retaining $\mathrm{CO}_{2}$ whilst the measurement is being made. It is also unreliable if the subject is developing

Table 7. Changes in stores of carbohydrate in sixteen subjects, calculated from the dietary intake and metabolic mixture

$\begin{array}{lccc}\text { Subject } & \begin{array}{c}\text { Net dietary } \\ \text { intake } \\ \text { (g/day) }\end{array} & \begin{array}{c}\text { Net tissue } \\ \text { oxidation } \\ \text { (g/day) }\end{array} & \begin{array}{c}\text { Tissue store } \\ \text { (g/4 days) }\end{array} \\ \text { Elizabeth } & 416 & 501 & -340 \\ \text { Tony } & 496 & 441 & +\mathbf{2 2 2} \\ \text { Michael } & 479 & \mathbf{2 6 0} & +876 \\ \text { John } & 656 & 522 & +536 \\ \text { David } & 466 & 100 & +\mathbf{1 4 6 4} \\ \text { Sam } & 479 & 299 & +720 \\ \text { Tom } & 487 & 336 & +604 \\ \text { Edgar } & 596 & 480 & +464 \\ \text { Betty } & 645 & 408 & +948 \\ \text { Pat } & 703 & 532 & +684 \\ \text { Lena } & 403 & 394 & +36 \\ \text { Georgette } & 360 & 275 & +340 \\ \text { May } & 403 & 287 & +464 \\ \text { Irene } & 446 & 439 & +28 \\ \text { Isobel } & 529 & 539 & -40 \\ \text { Ann } & 688 & 544 & +576\end{array}$

Table 8. The overall respiratory quotient during the control period in eight subjects

$\begin{array}{lcc}\text { Subject } & \begin{array}{c}\text { Calculated from } \\ \text { the respiratory } \\ \text { exchanges }\end{array} & \begin{array}{c}\text { Calculated from } \\ \text { the analyses of } \\ \text { the diets }\end{array} \\ \text { Tony } & 0.86 & 0.90 \\ \text { Michael } & 0.82 & 0.85 \\ \text { John } & 0.92 & 0.94 \\ \text { David } & 0.74 & 0.84 \\ \text { Sam } & 0.82 & 0.85 \\ \text { Tom } & 0.85 & 0.88 \\ \text { Betty } & 0.86 & 0.86 \\ \text { Pat } & 0.86 & 0.86\end{array}$

a metabolic acidosis or alkalosis, for instance as a result of muscular exercise or the secretion of an acid digestive juice. Such may have been the case on a few occasions, but these results are based on 250 measurements of the $\mathrm{RQ}$ taken at irregular intervals at all hours of the day and night. Further, all the subjects of necessity became experienced in giving samples of expired air. There was no evidence to suggest the presence of any systematic error.

An indication of the validity of the $R Q$ measurements is provided by the findings during the control periods, for which complete records over the $24 \mathrm{~h}$ period are available for eight subjects. Table 8 shows the calculated RQ of the metabolic mixture and of the control diet, on which the subject's weight was unchanged. Except in one 
subject, the calculated $\mathrm{RQ}$ of the metabolic mixture is not more than 0.04 below that of the diet. In these subjects the tissue utilization of carbohydrate can only have been slightly underestimated. The discrepancy was much greater in the case of David, a subject experienced in respiratory work, who consistently gave low values for the $\mathrm{RQ}$ during the control period and these did not rise during the period of overfeeding.

The increase in the carbohydrate stores could be accounted for by an increase in the muscle glycogen. The human body contains from 25 to $40 \mathrm{~kg}$ or more of muscle. A rise in concentration of muscle glycogen of $2 \%$ would thus increase the carbohydrate store from 500 to $800 \mathrm{~g}$. It is known that the glycogen content of human muscle can vary from 0.5 up to $4.0 \mathrm{~g} / 100 \mathrm{~g}$ (Hildes, Sherlock \& Walshe, I949).

Table 9. Changes in total water in sixteen subjects, calculated by difference from the changes in body-weight and in protein, fat and carbohydrate stores

\begin{tabular}{|c|c|c|c|}
\hline Subject & $\begin{array}{c}\text { Gain in } \\
\text { body-weight } \\
\text { (g/4 days) }\end{array}$ & $\begin{array}{l}\text { Caloric value } \\
\text { of weight gain } \\
(\mathrm{kcal} / \mathrm{g})\end{array}$ & $\begin{array}{l}\text { Gain in } \\
\text { body water } \\
\text { (g/4 days) }\end{array}$ \\
\hline Elizabeth & 1210 & $5 \cdot 4$ & 910 \\
\hline Tony & 2410 & $2: 7$ & I 540 \\
\hline Michael & 1360 & $5 \cdot 2$ & 90 \\
\hline John & 2400 & $3 \cdot 1$ & I 300 \\
\hline David & 830 & 6.3 & -750 \\
\hline Sam & 1300 & $5 \cdot 3$ & 160 \\
\hline Tom & 2190 & $3 \cdot 3$ & 1220 \\
\hline Edgar & 2660 & 3.0 & 1530 \\
\hline Betty & 1260 & $3 \cdot 1$ & 340 \\
\hline Pat & 1990 & $2 \cdot 4$ & 1070 \\
\hline Lena & 830 & $4 \cdot 6$ & 270 \\
\hline Georgette & 860 & $4 \cdot 5$ & 220 \\
\hline May & 400 & 10.1 & -410 \\
\hline Irene & 370 & 10.0 & -40 \\
\hline Isobel & 1500 & $2 \cdot 0$ & 1190 \\
\hline Ann & 5460 & $I \cdot I$ & 4490 \\
\hline
\end{tabular}

Changes in the water content of the body. In Table 9 values are given for the gain in body water calculated by subtracting from the gain in body-weight the changes in body protein, fat and carbohydrate (Tables $5-7$ ). For each subject the full water balance was also calculated from measurements of the dietary water intake, the metabolic water, the urinary water, the faecal water and the insensible water loss. However for arithmetical reasons (Passmore et al. 1959) the two calculations must give the same results for the change in body water.

Table 9 shows that over the 4 days of overfeeding body water gain ranged from $-750 \mathrm{~g}$ to $+\mathrm{I} 540 \mathrm{~g}$ in the subjects who had previously been on a diet which met their energy requirements. Both gains and losses were found in both thin and obese subjects and were unrelated to either the nature or the extent of overfeeding. Wide variations in the water content of the body are known to occur in the daily life of normal people (Robinson \& Watson, I965). Water retention must occur with overfeeding, unless the tissues of the body are to become more concentrated, and amongst other factors the sodium intake with a high-calorie diet will have some influence. The obese subjects in whom there was little or no gain in body water all appeared to find the overfeeding 
difficult and were probably considerably stressed by the experience. Tony, John, Tom, Edgar and Pat, who all gained over $\mathrm{I} \mathrm{kg}$ of water, found much less difficulty in consuming the diet. The enormous amount of water gained by Ann can be accounted for by the fact that just previously she had been on a reducing regime, known to cause marked losses of water (Passmore et al. I959).

The large variations in the water laid down account for the variations in the calorie value of the weight gain (Table 9).

\section{DISCUSSION}

These experiments provide no evidence that the body of either thin or obese human subjects can adapt immediately to a dietary excess. In particular, the gut appears unable to reject any part of the excess calories and the tissues fail to oxidize a significant amount of the surplus nutrients. Inevitably, this surplus increases the stores in tissues and, in the first instance at least, a significant increase in the body's content of carbohydrate occurs. The actual gain in body-weight is very variable on account of the variable body water. These experiments, of course, provide no evidence of how the body reacts to a long period of constant slight overfeeding. They do indicate that neither fat nor thin subjects possess any mechanism immediately available for protection against the consequence of a short period of gluttony.

This is not surprising. Man has evolved in an environment where his food supply has been limited and uncertain. Our ancestors, like many of our contemporaries, were frequently, and sometimes for long periods, forced to subsist on diets which did not meet their energy requirements. The development of adaptive mechanisms, which protected them during periods of partial starvation, had survival value. Only in the last few decades have large numbers of men and women lived in an environment where large quantities of food have been readily available and the need for physical work slight. There has been little opportunity for the evolution of physiological mechanisms which might protect against gluttony. That individuals have been reported who weigh over $600 \mathrm{lb}$ (Anonymous, 1965 ) indicates that there is no escape from progressive obesity for a person who continues to eat in excess of his requirements.

We are indebted to Miss Anna Gibson, the dietitian in charge of the Metabolic Unit, for her careful supervision of the diets. Dr Christian Thin and Mrs Sheila Jacobs have assisted greatly with the analytical work in the later experiments. Without the patient co-operation of the subjects in what was sometimes an unpleasant experience this work would have been impossible. This research programme has been supported by a grant from the Secretary of State for Scotland. 


\section{REFERENCES}

Anonymous (1965). Time 30 July 1965.

Atwater, W. O. \& Bryant, A. P. (1900). Rep. Storrs agric. Exp. Stn p. 180.

Davidson, S. \& Passmore, R. (1966). Human Nutrition and Dietetics, 3 rd ed. Edinburgh: Livingstone.

Durnin, J. V. G. A. \& Passmore, R. (1967). Energy, Work and Leisure. London: Heinemann.

Grafe, E. \& Graham, D. (I91 I). Hoppe-Seyler's Z. physiol. Chem. 73, I.

Hildes, J. A., Sherlock, S. \& Walshe, V. (1949). Clin. Sci. 7, 287.

Munro, H. N. (1964). In Mammalian Protein Metabolism. Vol. 1, p. 38. [H. N. Munro and J. B. Allison, editors.] New York: Academic Press Inc.

Odier, J. \& Mach, R. S. (I949). Praxis. 38, 384 . Quoted by McCance, R. A. \& Widdowson, E. M. (I95I). Proc. R. Soc. B I38, II5.

Passmore, R., Meiklejohn, A. P., Dewar, A. D. \& Thow, R. K. (I955a). Br. F. Nutr. 9, 20.

Passmore, R., Meiklejohn, A. P., Dewar, A. D. \& Thow, R. K. (r955b). Br. F. Nutr. 9, 27.

Passmore, R., Strong, J. A. \& Ritchie, F. J. (1959). Br. J. Nutr. 13, 17.

Passmore, R., Strong, J. A., Swindells, Y. E. \& el Din, N. (1963). Br. F. Nutr. 17, 373 .

Robinson, M. F. \& Watson, P. E. (1965). Br. F. Nutr. 19, 225. 